Solís-Marín, F.A., Laguarda-Figueras, A., Conejeros-

Vargas, C.A., Caballero-Ochoa, A.A., \& Durán-

González, A. (2021). Expansion of the genus

Massinium (Holothuroidea: Thyonidae) to the

American continent and description of a new species.

Revista de Biología Tropical, 69(S1), 304-311. DOI

10.15517/rbt.v69iSuppl.1.46363

DOI 10.15517/rbt.v69iSuppl.1.46363

\title{
Expansion of the genus Massinium (Holothuroidea: Thyonidae) to the American continent and description of a new species
}

Francisco A. Solís-Marín ${ }^{1 *}$

Alfredo Laguarda-Figueras ${ }^{1}$

Carlos A. Conejeros-Vargas ${ }^{2}$

Andrea A. Caballero-Ochoa ${ }^{3,4}$

Alicia Durán-González ${ }^{1}$

1. Colección Nacional de Equinodermos “Dra. Ma. Elena Caso Muñoz”, Laboratorio de Sistemática y Ecología de Equinodermos, Instituto de Ciencias del Mar y Limnología, Universidad Nacional Autónoma de México, Coyoacán, Ciudad de México, México; fasolis@cmarl.unam.mx (*Correspondence), laguarda@cmarl.unam.mx, aliciad@cmarl.unam.mx

2. Posgrado en Ciencias del Mar y Limnología, Universidad Nacional Autónoma de México, Av. Ciudad Universitaria, Coyoacán, Ciudad de México, México; conejeros@ciencias.unam.mx

3. Facultad de Ciencias, Universidad Nacional Autónoma de México. Circuito exterior s/n, Ciudad de México, México; a.caballero.ochoa@ciencias.unam.mx

4. Posgrado en Ciencias Biológicas, Universidad Nacional Autónoma de México, Av. Ciudad Universitaria 3000, C.P. 04510, Coyoacán, Ciudad de México, México.

Received 07-VII-2020. Corrected 25-VIII-2020. Accepted 06-XI-2020.

\begin{abstract}
Introduction: The genus Massinium includes 11 species, most from the Indo Pacific Ocean, and had not previously being reported from the American continent. Objective: To present the new record of the genus Massinium and describe a new species of this genus. Methods: Material collection was done by SCUBA-diving to depths of a maximum of $9 \mathrm{~m}$. Results: Massinium ocumichoensis sp. nov. is described from seven specimens that extends the range of the genus to the American continent (Guerrero, Michoacan and Jalisco, Mexico). The new species lives in sandy-rocky substrata, from 2 to $16 \mathrm{~m}$ deep. It is distinguished from its congeneric species by a combination of morphological characters: mid-dorsal slightly bigger pseudobuttons $(40-60 \mu \mathrm{m})$, and tables in the body wall. A taxonomic key for distinguishing the species of Massinium is provided. Conclusions: The geographic range of the genus Massinium is extended to the Mexican Pacific with M. ocumichoensis sp. nov.
\end{abstract}

Key words: Echinodermata; Dendrochirotida; biodiversity; taxonomy; new record.

The order Dendrochirotida is the most diverse holothuroid order of the world (Prata \& Christoffersen, 2016). It is represented by the families Cucumariidae, Phyllophoridae, Psolidae, Sclerodactylidae and Thyonidae in the Mexican Pacific waters (Solís-Marín et al., 2013). The family Thyonidae Panning, 1949, sensu Smirnov (2012) is composed of
Dendrochirotida with 10-20 tentacles, tube feet scattered all over the body or restricted to the radii, the calcareous ring is segmented, the ossicles are tables with two or four pillars and/or plates; sometimes baskets present. The family includes four subfamilies: Thyoninae, Thyonininae, Hemithyoninae and Semperiellinae (Smirnov, 2012; Thandar, 2017). The 
genus Massinium Samyn \& Thandar, 2003 was included in the subfamily Semperiellinae Heding \& Panning, 1954 by Thandar (2017), this genus was erected to accommodate sea cucumbers which have the posterior processes of their tubular calcareous ring distally joined to form a ring-like structure around the esophagus and body wall with granuliform rods and/or rosette-shaped deposits and tables. Samyn and Thandar (2003) and Samyn, Thandar, and VandenSpiegel (2010) included six species in the genus: the Australian endemic M. granulosum Samyn, Thandar and VandenSpiegel, 2010; the New Caledonian endemic M. albicans Samyn, Thandar and VandenSpiegel, 2010; the central Indo-Pacific M. magnum (Ludwig, 1882), the southern African endemics M. arthroprocessum (Thandar, 1989), M. maculosum Samyn \& Thandar, 2003 and M. dissimilis (Cherbonnier, 1988) from Madagascar. Later O’Loughlin, Barmos, and VandenSpiegel (2012) included three more Australian endemic species: $M$. melanieae O'Loughlin in O'Loughlin et al. (2012), M. vimsi O'Loughlin in O'Loughlin et al. (2012) and M. watsonae O'Loughlin in O'Loughlin et al. (2012). Two years later O'Loughlin, Mackenzie, and VandenSpiegel (2014) included the Australian endemics M. bonapartum O'Loughlin in O'Loughlin et al. (2014) and M. keesingi O'Loughlin in O'Loughlin et al. (2014). Today Massinium includes 11 species, most from the Indo Pacific Ocean (WoRMS, 2020).

There are no previous records of the genus on the American continent waters. Seven specimens were collected along the Mexican Pacific, representing a new record of the genus and a new species.

\section{MATERIALS AND METHODS}

During recent surveys of the echinoderm fauna of the Mexican Pacific, seven specimens belonging to this new species were found. Collection was done by SCUBA-diving to depths of a maximum of $9 \mathrm{~m}$. Specimens were anaesthetized in a solution of $4 \%$ magnesium chloride and seawater. After properly labelled, fixation of the specimens was done with $70 \%$ ethyl alcohol. All measurements were obtained from fixed specimens. Ossicles were extracted from the body wall (anterior, medium and posterior region) introvert and tentacles. The tissue was dissolved in fresh household bleach (5-6.5 $\%$ ) in centrifuge tubes. After centrifugation at $1000 \mathrm{rpm}$ for $10 \mathrm{~min}$, bleach was pipetted off and the ossicles were rinsed and centrifuged with distilled water that was pipetted off afterwards. The same process was done with 70 , 80, and $95 \%$ ethanol. Absolute ethanol was added to the ossicles, and finally a small aliquot was taken and placed to dry on a cylindrical double-coated conductive carbon tape stub. Then it was sputter coated with gold $2.5 \mathrm{kV}$ in the ionizer Polaron E3000 for $3 \mathrm{~min}$ and photographed using a Hitachi S-2460N scanning electron microscope (SEM). Photographs of the holotype specimen were taken using a Leica DFC490 digital camera, and a Leica Z16 APOA stereomicroscope. The examined material is deposited in the ICML-UNAM and LACM. Zoobank link: http://zoobank.org/ urn:1sid:zoobank.org:pub:1C0A2F30-80654C9C-855B-9FFD681C5A7D

Abbreviations: ICML-UNAM: Coleccion Nacional de Equinodermos, Instituto de Ciencias del Mar y Limnologia, Universidad Nacional Autonoma de Mexico, Mexico City. LACM: Natural History Museum, Los Angeles County Museum, Los Angeles, California, USA. TL: Total Length.

\section{ANALYSIS}

Order Dendrochirotida Grube, 1840

Family Thyonidae Panning, 1949

(sensu Smirnov, 2012)

Diagnosis: Dendrochirotida with 10-20 tentacles. Tube feet scattered all over body or restricted to the radii. Calcareous ring segmented. Ring often tubular, forked processes of radial segments long, prominent. Inter-radial segments often strongly elongated basally fused with processes of radial 
segments; both calcareous ring segments, and processes subdivided into many pieces. Ossicles: tables with two or four pillars and/or plates; sometimes baskets present (modified from Smirnov, 2012).

Subfamily Semperiellinae Heding \& Panning, 1954

Diagnosis: (modified from O'Loughlin et al., 2012 and Smirnov, 2012). A polytentaculate subfamily of Thyonidae with 15-20 tentacles. Tube feet lying along radii or scattered over entire body. Calcareous ring well developed, often tubular, radial and inter-radial plates always broken into a mosaic of pieces, posterior processes of radial and often the inter-radial plates sub-divided, and processes of radial and sometimes the inter-radial plates joining posteriorly, the latter forming a ribbon-like ring surrounding the water vascular ring. Body wall ossicles 2-4 pillared tables or their derivatives.

Genus Massinium Samyn \& Thandar, 2003

Diagnosis: (modified from O'Loughlin et al., 2014). Slim, elongated body, sometimes semi-spherical forms; anterior and posterior parts of the body narrow, with oral and anal dorsal orientations; 20 dendritic tentacles arranged in two circles of ten large outer and ten small inner (proximal peri-oral); calcareous ring elongated, tubular, with both radial and inter-radial plates fragmented into a mosaic of pieces, and posterior prolongations linked distally to form inter-radial oval non-calcified spaces beneath the water vascular ring; polian vesicles from one to four; ossicles variably include granuliform rods, rosettes, pseudobuttons and tables; table spires with one or two or three or reduced pillars.

Type especies: Massinium maculosum Samyn \& Thandar, 2003 (by original designation).
Massinium ocumichoensis sp. nov.

Fig. 1A, 1B, 1C, Fig. 2A, 2B, 2C, $2 \mathrm{D}, 2 \mathrm{E}, 2 \mathrm{~F}, 2 \mathrm{G}, 2 \mathrm{H}, 2 \mathrm{I}$

Type specimen: Holotype, ICML-UNAM 10078, Faro de Bucerias, Aquila, Michoacan, Mexico, Pacific Ocean (18²1'12.21' N \& $103^{\circ} 31^{\prime} 03.06^{\prime}$ " W), $5 \mathrm{~m}$, sandy-rocky bottom, January $8^{\text {th }}$ 2013, Coll. Solis-Marin, F. A., Hooker, Y., Arriaga-Ochoa. J. A., Hernandez, Q.

Type locality: Faro de Bucerias, Michoacan, Mexico, Pacific Ocean (18 $21^{\prime} 12.49^{\prime \prime}$ N \& $103^{\circ} 31^{\prime} 03.80^{\prime}$ 'W), $5 \mathrm{~m}$, sandy-rocky bottom, January $8^{\text {th }} 2012$.

Other type material: Paratypes, one specimen, ICML-UNAM 18367, same data as the holotype; one specimen, LACM E.201615.1, Isla Cocinas, Chamela Bay, Jalisco, Mexico, Pacific Ocean (19³2'47.20" N \& $\left.105^{\circ} 06^{\prime} 34.20^{\prime \prime} \mathrm{W}\right), 7 \mathrm{~m}$, sandy-rocky bottom, November 23 2016, Coll. Solis-Marin, F. A., Caballero-Ochoa A. A., Conejeros-Vargas, C. A., Marquez-Borras, F. and Ayala-Aguilera, P. A.; one specimen, ICML-UNAM 8504, La Cagada, Acapulco Bay, Guerrero, Mexico, Pacific Ocean (16 49'28.50" N \& 99॰55'03.62” W), 9 m, sandy-rocky bottom, May 26 2006, Coll. Solis-Marin, F. A., HoneyEscandon, M.; one specimen, ICML-UNAM 8952, Isla Cocinas, Chamela Bay, Jalisco, Mexico, Pacific Ocean (19³3'45.40" N \& $\left.105^{\circ} 06^{\prime} 32.90^{\prime \prime} \mathrm{W}\right), 2 \mathrm{~m}$, sandy-rocky bottom, November 17 2008, Coll. Solis-Marin, F. A., Honey-Escandon, M.; one specimen, ICMLUNAM 11912, Isla Pajarera, external area, Chamela Bay, Jalisco, Mexico, Pacific Ocean (19³3'27.70" N \& 10507'0.60" W), 16 m, sandy-rocky bottom, November 13 2013, Coll. Solis-Marin, F. A., Arriaga-Ochoa, J. A., Hernandez, Q., Pineda-Enriquez, T., CaballeroOchoa, A. A.; 2 specimens, ICML-UNAM 12627, Playa Caleta, Acapulco Bay, Guerrero, Mexico (1649'49.16” N \& 9954'03.88” W), 
$4.5 \mathrm{~m}$, sandy-rocky bottom, November 16 2015, Coll. Solis-Marin, F. A., Hernández, Q., Parada, T.; Márquez Borrás, F., Teyssier. E.; one specimen, ICML-UNAM 13144, Balandra Bay, Gulf of California, Baja California Sur, Mexico (24¹9'26.94" N \& 110¹9'34.46" W), 1 m, sandy-rocky bottom, March 23 2017, Coll. Solis-Marin, F. A., Caballero-Ochoa, A. A., Conejeros-Vargas, C. A., Ayala Aguirre P., Calderón-Gutiérrez, F.; one specimen, ICMLUNAM 18368, Isla Cocinas, Chamela Bay, Jalisco, Mexico, Pacific Ocean (19'32'46" N \& $\left.105^{\circ} 06^{\prime} 32^{\prime \prime} \mathrm{W}\right), 4-5 \mathrm{~m}$, sandy-rocky bottom, November 15 2010, Coll. Solis-Marin, F. A., Honey-Escandon, M.

Diagnosis: Small-sized (60-74 mm TL), U-shaped thyonid with bloated mid-body and relatively short anterior and posterior ends. Anus surrounded by ten small papillae, variously developed. Tube feet scattered over entire body. Ossicles of body wall two pillared tables and pseudobuttons, often with minute perforations. Introvert ossicles include pseudobuttons, tables and rosettes. Tentacles of outer ring with smooth, slightly curved rods, perforated at the ends, external tips of the outer tentacles ring devoid of ossicles, tentacles of inner ring with rods and rosettes. Body color off-white to grey, mottled with dark brown, sometimes black; tentacle dendritic branches black, trunks transparent with black moles.

Etymology: The name ocumichoensis refers to Ocumicho, Michoacan (same state as the type locality), a famous small town where folk artisans create colorful clay magical devils and beasts.

Description of holotype: Specimen entire, well preserved, dissected (Fig. 1A). Mouth anterior, anus posterior, slightly developed anal papillae; body wall firm, leathery, rather thin (0.8-1 mm), slightly rough to the touch. Body

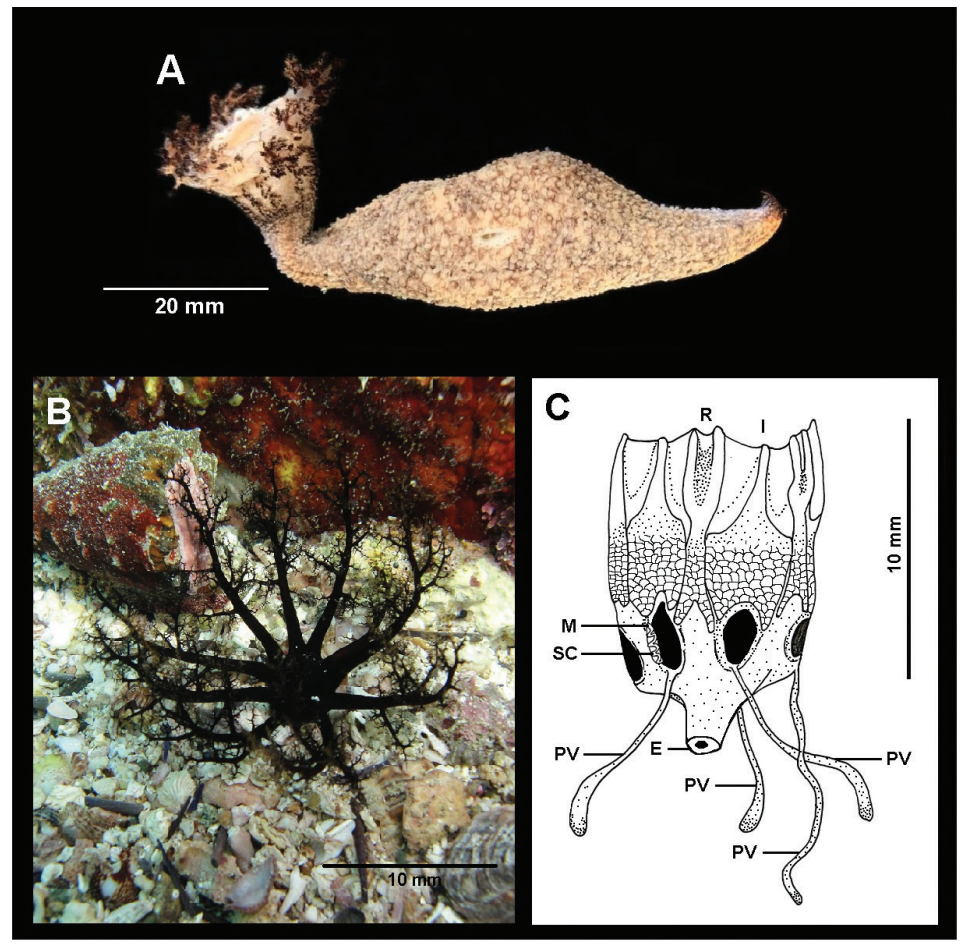

Fig. 1. Massinium ocumichoensis sp. nov. A. External, lateral view of holotype ICML-UNAM 10078. B. Tentacle crown of the holotype in situ. C. Calcareous ring. R. Radial plates. I. Inter-radial plate. M. Madreporite. SC. Stone canal. PV. Polian vesicles. E. Esophagus. 
form cylindrical, slightly contracted, bloated, with narrow anterior and posterior ends. Introvert well extended, attached to the main body. Length of specimen along ventral surface 74 $\mathrm{mm}$; along dorsal surface $64 \mathrm{~mm}$; height of mid-body approximately $18 \mathrm{~mm}$; anterior and posterior ends approximately 20 and $18 \mathrm{~mm}$ long; introvert $8 \mathrm{~mm}$ long. Coloration of body and introvert beige brown with brown small moles. Tube feet of body wall beige, numerous, small, mostly retracted, uniformly scattered over entire body, very small suckers; close cover ventrally and around mouth and anus; tube feet of introvert brownish, darker proximally, aligned in radial areas in two welldefined rows, absent in distal $3 \mathrm{~mm}$. Tentacles 20 , ten large, ten small, arranged in two rows (Fig. 1B); outer tentacles, when alive, 35-40 mm long, black tips, middle part shaft whitish with black moles; when preserved the tentacles are highly contracted $(9 \mathrm{~mm})$. Calcareous ring short $(10 \mathrm{~mm})$, tubular, composite; both radial and interradial plates broken into a mosaic; radial plates elongated, with a shallow central notch, central part constricted and posterior part divided in two short tails, inter-radial plates triangular pointed anteriorly, large oval un-calcified posterior section closed distally by non-calcified link; one madreporite, well calcified, stone canal scalloped and attached to one extension of the interradial plate posterior processes of the calcareous ring (Fig. 1C); four polian vesicles (Fig. 1C); respiratory trees extending the length of the coelom.

Ossicles in mid-body wall are large pseudobuttons (40-60 $\mu \mathrm{m})$ (Fig. 2A), and tables sparse dorsally (Fig. 2B) table disc outlines irregularly round, typically four larger central and some small outer perforations, margin smooth or spinous, discs up to $42 \mu \mathrm{m}$ wide; tables frequently with two pillars, low or residual, few thick blunt apical spines. Anterior and posterior body wall areas with small pseudobuttons (15-30 $\mu \mathrm{m})$ (Fig. 2A). Oral disc with abundant tables with discs up to $35 \mu \mathrm{m}$ long, irregularly oval, many perforations, margins smooth; spires short, up to $10 \mu \mathrm{m}$ tall, two pillars, rarely single, one to two median perforations, short apical spines typically splayed (Fig.
2B). Peri-anal body wall with abundant tables similar to those in the mid-body wall; some rods with distal perforations, rods up to $80 \mu \mathrm{m}$ long; anal papillae with small multi-layered anal scales about $45 \mu \mathrm{m}$ long. Introvert with pseudobuttons, tables and rosettes (Fig. 2C, $2 \mathrm{D}, 2 \mathrm{E}$ ). Tube feet with endplates, up to $40-45$ $\mu \mathrm{m}$ diameters, margin thick (Fig. 2F), with support ossicles as smooth rods with perforated ends (Fig. 2G). Tentacles of outer ring with abundant simple slightly curved rods perforated at the ends and granuliform rod ossicles; simple rods up to $50 \mu \mathrm{m}$ long with perforated ends; granuliform rods up to $55 \mu \mathrm{m}$ long with short rod widened distally with many small perforations created by dendritic branch fusing (Fig. 2H); abundant well-elaborated rosettes (Fig. 2I). External tips of the outer tentacles ring devoid of ossicles, tentacles of inner ring with rods and rosettes.

Body live color off-white to grey, mottled with dark brown, sometimes black; tentacle dendritic branches black, trunks transparent with black moles; color preserved off white to pale beige, tube feet beige, tentacles black, trunks off-beige to black (Fig. 1B).

Description of paratypes: The paratypes are from 40 to $74 \mathrm{~mm}$ long. The ossicles of the body wall and other parts of the body are similar to those in the holotype. The calcareous ring in $40-50 \mathrm{~mm}$ TL specimens is small and the mosaic is very difficult to observe. Preserved specimens color varies from light to dark grey. Some specimens have light beige body and beige to brown tube feet.

Distribution and habitat: Massinium ocumichoensis sp. nov. have been recorded in the Mexican Pacific at Balandra Bay, Gulf of California, Baja California Sur; Isla Cocinas, Isla Pajarera, Chamela Bay, Jalisco; Faro de Bucerias, Aquila, Michoacan and Acapulco Bay, Guerrero, Mexico. Occur in sandy-rocky substrata, from 1 to $16 \mathrm{~m}$ deep.

Ecology: This species lives buried deeply in sand (10-15 cm deep), under boulders and 


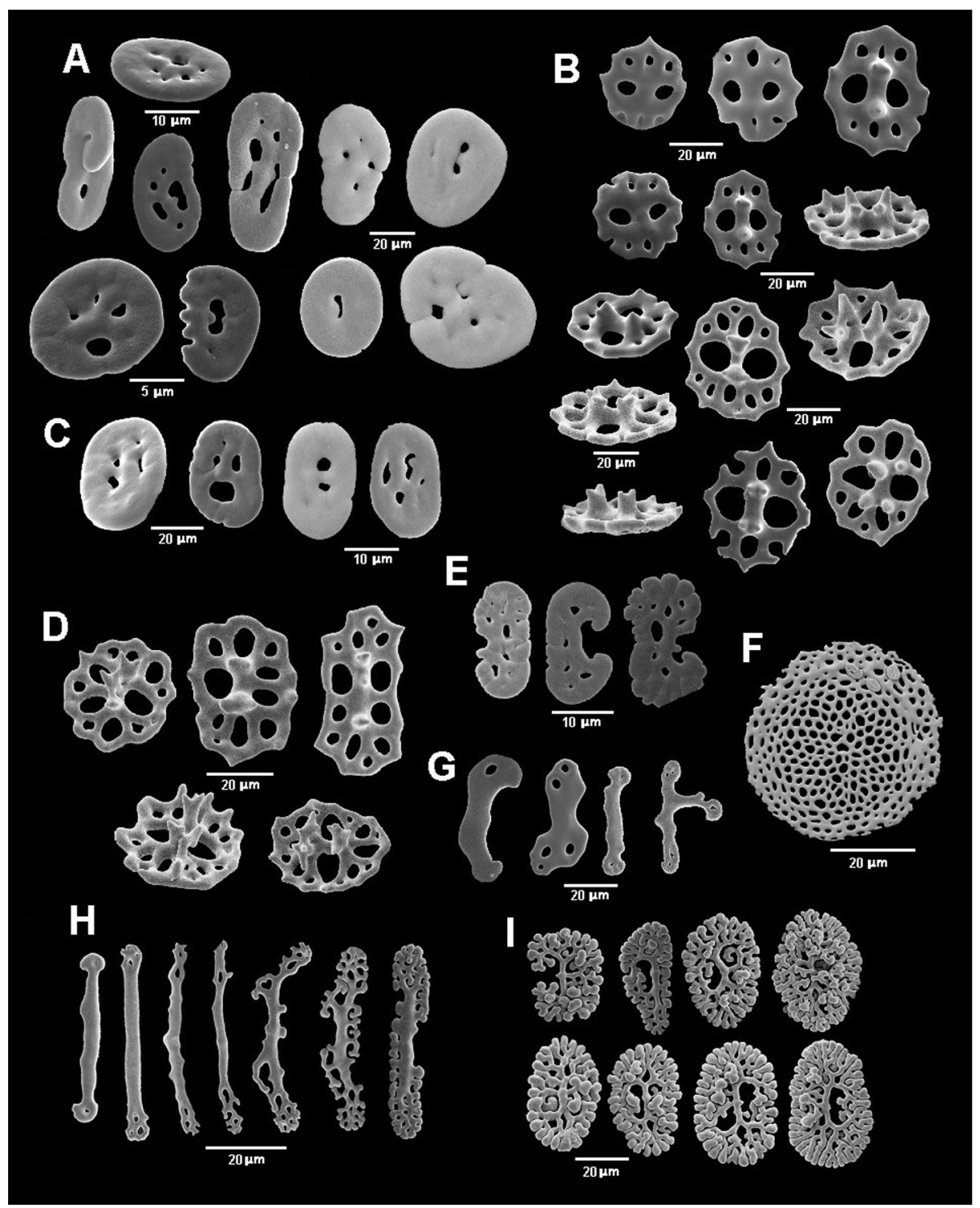

Fig. 2. Massinium ocumichoensis sp. nov., holotype ICML-UNAM 10078. A. Pseudobuttons from body wall. B. Tables from body wall. C. Pseudobuttons from introvert. D. Tables from introvert. E. Rosettes from introvert. F. Endplate of tube feet. G. Rods from tube feet. H. Simple and granuliform rods from tentacles. I. Rosettes from tentacles.

rocks exposing its tentacle crown only when feeding. Upon slightest disturbance, even shading, the tentacle crown and the introvert are swiftly retracted into the body leaving no trace of the animal.

Remarks: Massinium ocumichoensis sp. nov. is morphologically related to $M$. maculosum Samyn \& Thandar, 2003 in having pseudobuttons in the body wall, and introvert with tables and rosettes, however mid-dorsal pseudobuttons are slightly bigger in $\mathrm{M}$. ocumichoensis sp. nov. $(40-60 \mu \mathrm{m})$, but smaller (14-27 $\mu \mathrm{m})$, thicker, and mainly not perforated in M. maculosum (Samyn \& Thandar, 2003; Fig. 2B, 2C). Moreover, M. maculosum doesn't 
have tables in the body wall as M. ocumichoensis sp. nov., it only has tables in the introvert tube feet, ventral tube feet and anal papillae which possess a high spire $(50-75 \mu \mathrm{m})$ in comparison with those in M. ocumichoensis sp. nov. which are very short $(10 \mu \mathrm{m})$ or with an almost absent spire. When alive M. ocumichoensis sp. nov. has longer outer tentacles $(35-40 \mathrm{~mm})$ than those in M. maculosum (30 mm) (Samyn \& Thandar, 2003).

M. ocumichoensis sp. nov. is distinguished from other species in the genus by the combination of morphological characters shown in the taxonomic key.

\section{Key to the species of Massinium (modified from O'Loughlin et al., 2014)}

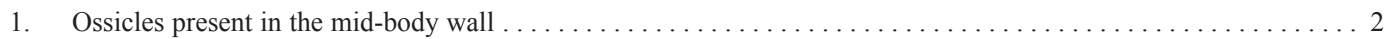

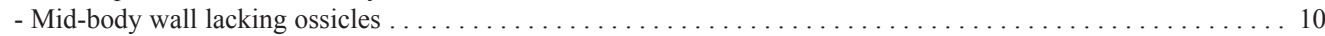

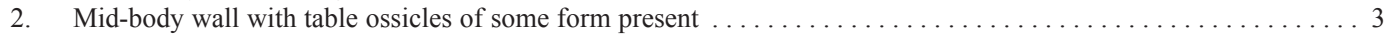

- Mid-body wall lacking any form of table ossicles $\ldots \ldots \ldots \ldots \ldots \ldots \ldots \ldots \ldots \ldots \ldots \ldots \ldots \ldots$

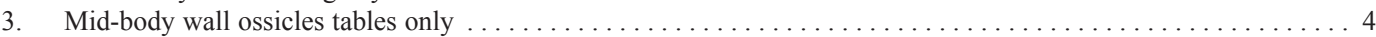

- Mid-body wall ossicles tables and additional ossicle forms $\ldots \ldots \ldots \ldots \ldots \ldots \ldots \ldots \ldots \ldots \ldots \ldots \ldots$

4. Peri-oral table spires well developed, typically with long, splayed, pointed apical spines .... M. bonapartum (NW Australia)

- Peri-oral table spires frequently absent or reduced, few short apical spines . . . . . . . M. keesingi (NW Australia)

5. Mid-body with developed table ossicles, pseudobuttons and rounded plates . . . . . . . . M. dissimilis (Madagascar) - Mid-body with tables or reduced table ossicles, pseudobuttons and rosettes $\ldots \ldots \ldots \ldots \ldots \ldots \ldots \ldots \ldots$

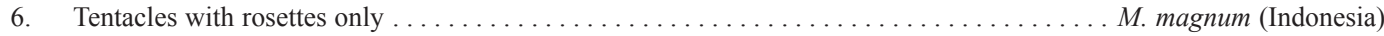
- Tentacles with granuliform rods and rosettes ............. ocumichoensis sp. nov. (NE Pacific, Mexico)

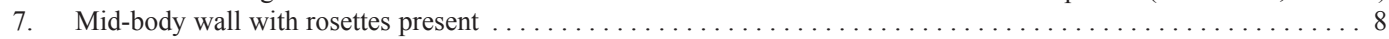

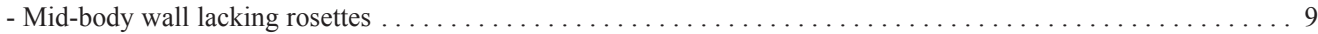

8. Introvert table discs irregular with predominantly four central perforations and single ring of smaller outer perforations; tentacles with rods and rosettes ................................. maculosum (South Africa) - Introvert table discs irregular with predominantly four central perforations and up to three rings of smaller outer perforations; tentacles with elongate rod-rosettes . . . . . . . . . . . . . . . albicans (New Caledonia)

9. Mid-body ossicles predominantly short, thick, irregular, rarely perforate, granuliform rods; tentacles with rosette ossi-

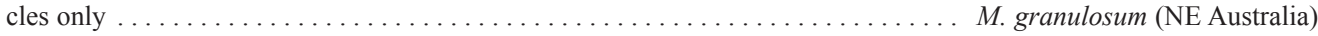
- Mid-body ossicles predominantly U-shaped, distally perforate rods; tentacles

with rod ossicles only $\ldots \ldots \ldots \ldots \ldots \ldots \ldots \ldots \ldots \ldots \ldots \ldots \ldots \ldots \ldots \ldots$ arthroprocessum (South Africa)

10. Large and small tube feet uniformly distributed; 4 polian vesicles; peri-anal body

wall with table ossicles $\ldots \ldots \ldots \ldots \ldots \ldots \ldots \ldots \ldots \ldots \ldots \ldots \ldots \ldots \ldots \ldots \ldots \ldots \ldots \ldots \ldots$ melanieae (Great Australian Bight)

- Tube feet not uniformly distributed; fewer than 4 polian vesicles; peri-anal body wall lacking table ossicles . . . 11

11. Tube feet scattered dorsally, more prominent ventrally; peri-oral table discs with up to 20 perforations; tentacles with rods and rare rosettes $\ldots \ldots \ldots \ldots \ldots \ldots \ldots \ldots \ldots \ldots \ldots \ldots \ldots \ldots \ldots \ldots \ldots \ldots \ldots \ldots \ldots$ vimsi (Bass Strait, SE Australia) - Tube feet more concentrated along longitudinal muscles; peri-oral table discs with up to 40 perforations; tentacles with rare fine rods, lacking rosettes $\ldots \ldots \ldots \ldots \ldots \ldots \ldots \ldots \ldots \ldots \ldots \ldots$ watsonae (SE Tasmania, Australia)

Ethical statement: authors declare that they all agree with this publication and made significant contributions; that there is no conflict of interest of any kind; and that we followed all pertinent ethical and legal procedures and requirements. All financial sources are fully and clearly stated in the acknowledgements section. A signed document has been filed in the journal archives.

\section{ACKNOWLEDGMENTS}

To Berenit Mendoza Garfias (Laboratorio de Microscopia Electrónica, Instituto de
Biología [IB], UNAM) for her technical support with the SEM work, and Susana Guzmán Gómez (LANABIO-IB, UNAM) for her photography technical assistance. To Scott Whitaker (Manager SEM, National Museum of National History, Smithsonian Institution, Washington, DC, USA) for his technical assistance when taking the SEM photographs presented in this work. Thanks to Ma. Esther Diupotex Chong (ICML, UNAM) for her technical support including type material in the Colección Nacional de Equinodermos (ICML, UNAM). The authors thank Magali Honey, Quetzalli Hernández, Julio Arriaga, Penélope 
Ayala, Francisco Borras and Tania Enriquez for helping in collecting the specimens. We would like to thank M. G. Lovegrove for his valuable comments on the manuscript's English and scientific content. CACV (scholarship holder 666781) thanks the Consejo Nacional de Ciencia y Tecnología (CONACyT) for his doctorate grant 722925.

\section{RESUMEN}

\section{Expansión del género Massinium \\ (Holothuroidea: Thyonidae) al continente americano y descripción de una nueva especie}

Introducción: El género Massinium incluye 11 especies, la mayoría del Océano Indo-Pacífico, y no se había reportado previamente en el continente americano. Objetivo: Presentar el nuevo registro del género Massinium y describir una nueva especie de este. Métodos: La recolección de material se realizó mediante buceo a una profundidad máxima de $9 \mathrm{~m}$. Resultados: Massinium ocumichoensis sp. nov. se describe a partir de siete ejemplares que extiende el rango de distribución del género al Continente Americano (Guerrero, Michoacán y Jalisco, México). La nueva especie vive en sustratos arenosos-rocosos, de 2 a $16 \mathrm{~m}$ de profundidad. Se distingue de sus especies congenéricas por una combinación de caracteres morfológicos: pseudobotones de la zona dorsal media ligeramente más grandes $(40-60 \mu \mathrm{m})$ y tablas en la pared del cuerpo. Se proporciona una clave taxonómica para distinguir las especies de Massinium. Conclusiones: El rango geográfico del género Massinium se extiende al Pacífico mexicano con M. ocumichoensis sp. nov.

Palabras clave: Echinodermata; Dendrochirotida; biodiversidad; taxonomía; nuevo registro.

\section{REFERENCES}

Cherbonnier, G. (1988). Echinodermes: Holothurides. Faune de Madagascar (Vol. 70). Paris: ORSTOM.

Grube, A.E. (1840). Actinien, Echinodermen Und Wurmer Des Adriatischen Und Mittlemeers. Königsberg: J.H. Bon.

Heding, S.G., \& Panning, A. (1954). Phyllophoridae. Eine bearbeitung der polytentaculaten dendrochiroten holothurien des zoologischen museums in Kopenhagen. Spolia Zoologica Musei Hauniensis, 13, 1-209.
Ludwig, H. (1882). List of the holothurians in the collection of the Leyden Museum. Notes Leyden Museum, 4(10), 127-137.

O’Loughlin, P.M., Barmos, S., \& VandenSpiegel, D. (2012). The phyllophorid sea cucumbers of southern Australia (Echinodermata: Holothuroidea: Dendrochirotida: Phyllophoridae). Memoirs of Museum Victoria, 69, 269-308.

O’Loughlin, P.M., Mackenzie, M., \& VandenSpiegel, D. (2014). New dendrochirotid sea cucumbers from northern Australia (Echinodermata: Holothuroidea: Dendrochirotida). Memoirs of Museum Victoria, 75, 5-23.

Panning, A. (1949). Revision of the family Cucumariidae, Holothurioidea, Dendolrichnota. Zoologische Jahrbücher Abteilung für Systematik, Ökologie Geographie Tiere, 78, 1-111.

Prata, J., \& Christoffersen, M.L. (2016). A new species of Pentamera Ayres, 1852 from the Brazilian coast (Holothuroidea, Dendrochirotida, Phyllophoridae). ZooKeys, 634, 1-14.

Samyn, Y., \& Thandar, A.S. (2003). Massinium, a new genus in the family Phyllophoridae (Echinodermata: Holothuroidea: Dendrochirotida) with description of a new south-west Indian Ocean species Massinium maculosum. Belgian Journal of Zoology, 133, 132-142.

Samyn, Y., Thandar, A.S., \& VandenSpiegel, D. (2010). Two new species in the phyllophorid genus Massinium (Echinodermata: Holothuroidea) with redescription of Massinium magnum. Zootaxa, 2399, 1-19.

Smirnov, A. (2012). System of the Class Holothuroidea. Paleontological Journal, 46, 793 -832.

Solís-Marín, F.A., Alvarado, J.J., Pérez-Ruzafa, A., Hernández, J.C., Morata, A., Marcos, C., ... Williams, S.M. (2013). Appendix. Biogeography and diversity of Latin American Echinoderms. In J.J. AlvaradoBarrientos \& F.A. Solís-Marín (Eds.), Echinoderm research and Diversity in Latin America (pp. 543654). Berlin and Heidelberg: Springer.

Thandar, A.S. (1989). A new species of a phyllophorid holothurian from southern Africa. Journal of Zoology, 219, 637-644.

Thandar, A.S. (2017). Two new subfamilies, three new species and a new subspecies of dendrochirotid sea cucumbers (Echinodermata: Holothuroidea). Zoota$x a, 4365(4), 410-420$.

WoRMS (2020). Massinium Samyn \& Thandar, 2003. Retrieved from http://www.marinespecies.org/aphia. php?p=taxdetails\&id=390820 on 2020-07-06 